\title{
HOW TO MAKE SHREDDED FOR FAMILY CONSUMPTION AND OPPORTUNITIES TO INCREASE FAMILY INCOME FOR MOTHERS RT 06 RW 09 AT PALMERAH
}

\author{
${ }^{1}$ Zulkarnain Arif, ${ }^{2}$ Maryani Maryani, ${ }^{3}$ Sarim Sarim \\ ${ }^{1,3}$ Hotel Management Department, Binus University, \\ ${ }^{2}$ Information System Departement School of Information System Binus University \\ arief.zulkarnain@binus.edu
}

Received: January $19^{\text {th }}, 2021 /$ Revised: February $18^{\text {th }} 2021 /$ Accepted: March $12^{\text {th }}, 2021$

\begin{abstract}
Fish is one of the food sources of animal protein (fish) which is widely liked and consumed by the public. This is aside from being relatively inexpensive and easy to obtain, as well as a high nutritional value that can maintain stability and health and can also improve brain intelligence in children. Shredded is one of the traditional processed food products that have long been known by the community. In general, shredded meat is made from beef and other animal meat. Shredded fish contains high enough nutritional components that are needed by our body. To build a culture that is cultured, spiritual, intellectual and intelligent, Palmerah Sub-district, West Jakarta has created thematic villages in six villages in its area. Palmerah Sub-district is a sub-district with a dense population. To support the smart village launched by Mr. Firman as the Head of Palmerah District. Where is a clean and healthy lifestyle and makes the village smart, by inviting families, especially children, to eat fish. One of the processing is by processing fish into shredded fish. Housewives and young people who have not worked are expected to make business opportunities to increase income and can also be consumed by families themselves. Training from the initial stage to completion requires eight months divided into several stages starting from needs analysis, introduction of fish and equipment and the manufacturing process, as well as packaging and the final stage is that the product can be sold through markets, stalls or through online media.
\end{abstract}

Keywords: Abon. Smart village, business opportunity, healthy

\section{Introduction}

West Jakarta has created thematic villages in six sub-districts in its territory to build a cultured, spiritual, intellectual and intelligent society, Palmerah District. Head of Palmerah Sub-district, Mr.Firmanudin said that the six thematic villages were created by each Climate Village in RW 07 of Slipi Village, Betawi Village in RW 06 and 04, Green Village, Colorful Vilage and Bright in RW 06, 07, 08, 09 and 12 Kelurahan Kota Bambu Selatan. Then Betawi cultural village in RW 05 and 07 Kelurahan Kota Bambu Utara, Literacy Village in RW 08 Kelurahan Jati Pulo and Kampung Awareness of Clean and Healthy Living Behavior in RW 09 Palmerah Village. So especially children must be diligent in eating fish because the benefits of fish are one of them for children's intelligence. We hope that the children from Palmerah Subdistrict are smart. 
Food ingredients with high protein content are prone to damage, including fish. Fish is an export commodity foodstuff that is widely consumed by the public. Fish undergo a fast process of decay compared to other food ingredients. The reason is, the chemical composition of fish is suitable as a growth medium for rotting bacteria or other microorganisms. In addition, fish fat contains a lot of unsaturated fatty acids, which are easily oxidized, causing a rancid odor. Fish need to be preserved because they rot easily. Thus, the fish preservation process needs to be known from all levels of society.

Traditional fish preservation aims to reduce the water content in the fish's body so that there is no opportunity for bacteria to breed. To get high quality curing results, good treatment is needed during the curing process. For example, the cleanliness of materials and tools is maintained, the fish used is still fresh, and the use of clean salt. One way to preserve fish is to process it into shredded fish. The types of fish that are good for shredded fish are tuna and marlin. The use of marlin fish will produce shredded fiber which is very good and soft. Fish is a source of high quality protein. Although the price of fish is relatively cheap, its nutritional value, especially its protein content, is higher. Fish protein is a more complete source of animal protein than vegetable protein. Fish has a high protein content, but low fat content so that it provides many health benefits for the human body.

Palmerah Subdistrict, including the West Jakarta Municipality, has an area of 755 ha. According to 2004 statistical data, the land area designation consists of housing 495.82 ha; industry 1.23 ha; offices 93.79 ha; garden $12.63 \mathrm{ha}$; agriculture $7.06 \mathrm{ha}$; idle land $24.15 \mathrm{ha}$; and others $120.32 \mathrm{ha}$.

Administratively, it consists of 6 urban villages, 61 RW, 714 RT, 48,776 families, 193,787 people and with a population density of 25,667 people / $\mathrm{km} 2$.

Palmerah District is a district with a dense population. To support the Thematic Village which was proclaimed by Mr. Firman as Head of Palmerah Sub-District. Where is the lifestyle. Living clean and healthy and making the village smart, by inviting families, especially children, to eat fish. One of the processing is by processing fish into shredded fish. It is hoped that housewives and young people who have not worked will provide business opportunities to increase income and can also be consumed by their families themselves.

The process of making shredded floss is relatively easy because it can be done by industry and households. The capital required is relatively small. Processing fish into floss can increase the shelf life, shelf life and economic value of fish compared to fresh or frozen form. Not only that, from a marketing perspective, shredded has long been known and accepted by all levels of society. The demand is also seasonal. Thus, the shredded business has bright prospects to be developed, both on an industrial and household scale.

Palmerah District is a sub-district with a dense population. To support the sub-district program to become a healthy village, one of them is by consuming fish. But society and children don't like fish. They need another form so that fish processing becomes more attractive so that children can certainly like the processed products, one of which is the Shredded form. The community, especially mothers in Palmerah sub-district, are average housewives, who only take care of the household. To increase family income, one of them is the opportunity to process fish into shredded fish which has high selling power and taste. So that the processing and selling of shredded fish can increase family income. This opportunity is also for young people who have not worked in the Palmerah area, so they need to be trained in making shredded fish so that later they can earn income.

\section{Literature Review}

Fish is a food ingredient that is very popular with all people. Fish as a food ingredient that contains high protein and contains essential amino acids needed by the body, in addition to its biological value reaching $90 \%$, with little binding tissue so that it is easily digested. The most important thing is that the price is much cheaper than other protein sources (Adawyah, R. 2007).

Many nutritionists have recommended fish as a healthy food that needs to be included in the daily diet. Fish is recommended for consumption compared to animal meat, especially for those who suffer from cholesterol and blood pressure or heart disorders (Suhartini and Hidayat, 2005). The advantages of fishery products compared to other animal products are as follows: 
1. A high enough protein content of $20 \%$ in the fish body is composed of amino acids that are patterned close to the pattern of amino acid requirements in the human body.

2. Fish meat is easily digested by the body because it contains a small amount of binding fabric (tendons).

3. Fish meat contains unsaturated fatty acids with very low cholesterol levels needed by the human body.

4. In addition, fish meat contains a number of minerals such as $\mathrm{K}, \mathrm{Cl}, \mathrm{P}, \mathrm{S}, \mathrm{Mg}, \mathrm{Ca}, \mathrm{Fe}, \mathrm{Ma}, \mathrm{Zn}$, $\mathrm{F}, \mathrm{Ar}, \mathrm{Cu}$ and $\mathrm{Y}$, as well as vitamins $\mathrm{A}$ and $\mathrm{D}$ in sufficient quantities to meet human needs. (Adawyah, R. 2007).

As we all know, fish is a perishable (rot) food material. In only about 8 hours since the fish is caught and landed, there will be a process of change that leads to damage. Therefore, in order for fish and other fishery products to be used as much as possible, their condition needs to be maintained. Processing is one way to keep fish from spoilage, so that they can be stored for a long time until it is time to be used as consumption (Adawyah, R. 2007). Salting is the traditional post-harvest processing or handling of fish. This is an example of adding $60 \mathrm{~g}(20 \%)$ breadfruit to shredded gouramy which is the best treatment which is preferred by 77 people $(96.25 \%)$. The characteristics of the appearance of golden yellow, the distinctive aroma of fish is still felt, the texture of the coarse fibers, soft and dry, the savory taste of the fish is still felt and the taste is medium, with a water content value of $1.06 \%, 24.92 \%$ protein content, fat content $18,24 \%$, ash content of $3.78 \%$ and fiber content of $0.93 \%$ (according to the Minister of Marine Affairs Regulation, 2018).

\section{Methods}

Community Development Program activities in Palmerah District will be carried out in three main stages, namely needs analysis, training, and evaluation of training results. The target of this activity is graduates who are not yet working, housewives, with the hope that they can earn income and become healthy citizens. The whole series of Comdev activities is planned to be completed within 8 months as shown in table 2. In the first month PKM activities will focus on needs analysis and training mapping. The second to eight months are the implementation of training activities and evaluation of training results. Meanwhile, in the eighth month the focus will be on making Comdev activity reports.

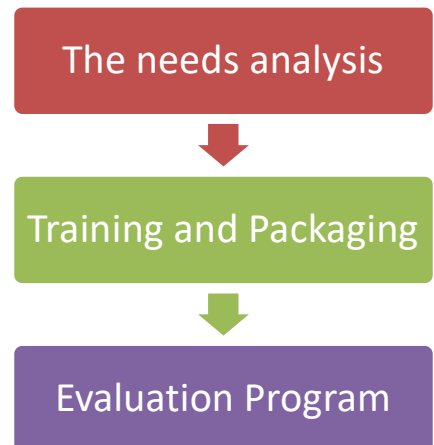

Figure 1. Step of Program Activities

The needs analysis aims to determine whether the housewives have made fish floss before. The results of the needs analysis are in the form of training mapping that will be presented at each training session. 
a. Raw Material Sorting

- One of the activities that determines the quality of the final product is sorting the raw materials. Raw material sorting is absolutely necessary in order to produce high quality products. Sorting can be done on a sorting table which is equipped with receptacles for fine materials and rejects. The container used can be a plastic basin or bucket.

b. Preliminary Process

- Clean the meat from the remaining bones, then wash it thoroughly

- Cut the meat into small pieces with a size of $5 \mathrm{~cm} \times 5 \mathrm{~cm}$ or bigger

c. Cooked

- Heat water in a pan, then add salt, lemongrass and bay leaves

- Enter the meat, then boil for 30-60 minutes until cooked and tender

d. Press I (first)

- Press or drain cooked meat

e. Shredding

- Gently mash the dry meat, then shreds it with a fork

f. Providing spices and coconut milk

- Combine the coriander powder, salt, granulated sugar, and flavoring in the shredded meat, then mix well.

- Grind shallots, garlic, and galangal until smooth, then mix into the meat

- Stir the meat mixture with the seasonings until blended. Pour the thick coconut milk into the meat mixture. Then stir until blended

g. Frying

- Fry shredded over low heat, stirring until cooked. Cirri shredded that has been ripe, namely a rustling sound when squeezed. Drain the shredded

h. Press II (second)

- Put the ripe shredded into the press. The trick, turn the pressing rod until the remaining oil is separated from the shredded.

i. Decomposition of Shredded

- Separate clumped shredded with a fork. Mix shredded with fried onions. Especially for spicy shredded, add ground chili to the shredded

j. Packaging

- Put the shredded into a plastic package, then weigh it and seal the packaging with a sealer. If a jar (closed container) is used, the shredded is then weighed, then the package is closed

- Label the package.

The training for making shredded fish was carried out through ZOOM CLOUD MEETING due to the current pandemic conditions so it was not possible to do it directly to the community. The activity was attended by 24 participants consisting of housewives and young people. The community needs to get a tutorial on how to properly process fish so that it becomes shredded with high quality and high selling power. So that our team carries out these activities. Chef Sarim makes fish using his chef clothes. All equipment and materials have been shared with the participants through materials in the form of a PPT file so that people can practice together or at least know the basic materials and how to make them. 

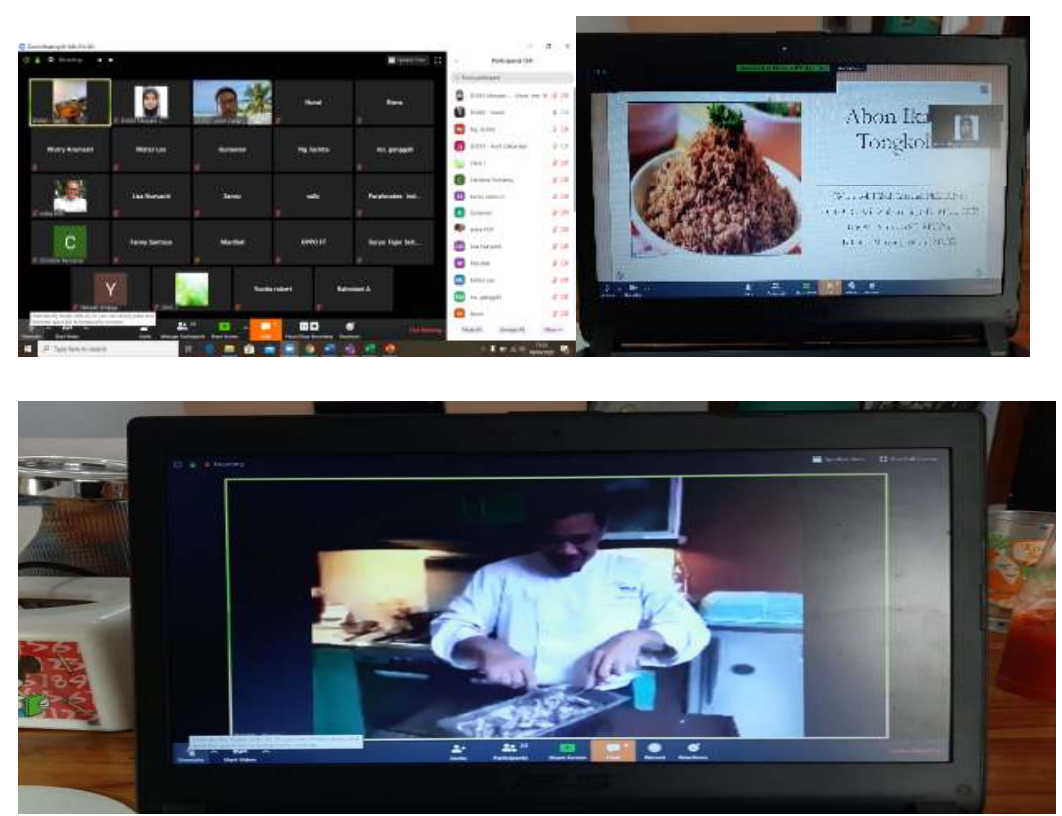

Picture 1. Photos of training session conducted by zoom

Ingredients :

- $1 \mathrm{~kg}$ of tuna

- 8 spring onions

- 6 cloves of garlic

- 5 large red chilies

- 1 tablespoon coriander (roasted)

- $4 \mathrm{~cm}$ galangal

- Palm sugar to taste

- $100 \mathrm{ml}$ coconut milk

- Cooking oil

- Salt

How to make:

1. Fish is washed thoroughly, remove the head then coat with salt and lime. Then steam for 15 minutes,separate the thorns and then shred them.

2. Blend coriander until smooth and set aside

3. Puree shallots, garlic, large red chilies, saute until fragrant and brown, add thick coconut milk, coriander, combed coconut sugar, crushed galangal, bay leaves.

4. Enter the shredded tuna then add enough salt, stir until the fish dries, remove from heat and set aside.

5. Prepare a frying pan and heat enough oil, fry the sauté fish with the spices until golden and dry, then remove and drain. Once cool, put it in an airtight jar or plstik so that it is durable and dry.

\section{Conclusion}

The current condition of the Pandemic does not allow face-to-face training. The training on making shredded fish was attended by 24 participants through media zoom. The goal is to help increase our income, we train the community and young people who have not worked to make shredded fish with 
high quality and high selling power as well as being consumed by the family itself. Video tutorial how to make fish shredded within the process of a Patent product. While the results of our analysis are made in the form of dedication papers.

\section{References}

Adawyah, R. (2007). Pengolahan dan pengawetan ikan. Jakarta: Bumi Aksara

Suhartini, S \& N. Hidayat. (2005). Olahan Ikan Segar. Surabaya: penerbit Trubusagrisarana

Peraturan Menteri Kelautan dan Perikanan Nomor 67 Tahun 2018 